\title{
IMPLEMENTASI PEMBELAJARAN DISCOVERY LEARNING YANG TERINTEGRASI PENDIDIKAN KARAKTER DALAM PELAJARAN BIOLOGI
}

\author{
Anis Sekarwati \\ SMK Negeri 2 Negara \\ email: anissekarwati@gmail.com
}

\begin{abstract}
The Background of this Classroom Action Research is the low motivation and student learning outcomes. This Classroom Action Research aims to find out the increased motivation and learning outcomes of students through Discovery Learning learning that integrates character education in learning biology on the subject of Living Classification. The design of this study is Classroom Action Research, consisting of 2 cycles, namely cycle I and cycle II. Each cycle consists of 3 meetings. This research approach is qualitative. The data analysis method is descriptive for both qualitative and quantitative data. The results showed that: 1) student learning motivation increased from cycle I by $75.40 \%$ to $81.59 \%$ in cycle II. 2) student learning outcomes increased from cycle I by $77.14 \%$ of students who completed learning increased to $88.57 \%$ in cycle II. Based on the data above that learning Discovery Learning model that is integrated with character education can increase student motivation and learning outcomes. The increase in the percentage of learning outcomes from cycle I to cycle II was $11.43 \%$ and the increase in learning motivation from cycle I to cycle II was $6.19 \%$.
\end{abstract}

Keyword: Motivation, Discovery learning, character education.

Abstrak: Latar belakang Penelitian Tindakan Kelas ini adalah rendahnya motivasi dan hasil belajar siswa. Penelitian Tindakan Kelas ini bertujuan untuk mengetahui peningkatan motivasi dan hasil belajar peserta didik melalui pembelajaran Discovery Learning yang terintegrasi pendidikan karakter dalam pembelajaran biologi pokok bahasan Klasifikasi Makhluk Hidup. Desain Penelitian ini adalah Penelitian Tindakan Kelas, terdiri atas 2 siklus yaitu siklus I dan siklus II. Setiap siklus terdiri dari 3 kali pertemuan. Pendekatan Penelitian ini adalah kualitatif. Metode analisis datanya adalah deskriptif baik untuk data kualitatif maupun data kuantitatif. Hasil penelitian menunjukkan bahwa: 1) motivasi belajar siswa meningkat dari siklus I sebesar 75,40\% menjadi 81,59\% pada siklus II. 2) hasil belajar siswa meningkat dari siklus I sebesar 77,14\% siswa yang tuntas belajar meningkat menjadi 88,57\% pada siklus II. Berdasarkan datadata diatas bahwa pembelajaran model Discovery Learning yang terintegrasi pendidikan karakter dapat meningkatkan motivasi dan hasil belajar siswa. Kenaikan prosentase hasil belajar dari siklus I ke siklus II sebesar 11,43\% dan kenaikan motivasi belajar dari siklus I ke siklus II sebesar 6,19\%.

Kata kunci: Motivasi, Discovery Learning, Pendidikan karakter

\section{PENDAHULUAN}

Mata Pelajaran Biologi merupakan mata pelajaran dasar bidang keahlian di SMK. Dalam Struktur Kurikulum SMK 2013 edisi revisi, Mata Pelajaran Biologi diberikan pada bidang keahlian tertentu dan hanya kelas $\mathrm{X}$. Jumlah jam pelajarannya pun hanya $2 \mathrm{jp} /$ minggu, di SMK lebih ditekankan pada mata pelajaran produktif. Menyiasati hal demikian, guru Biologi berusaha mengajarkan pelajaran biologi dengan menarik, contoh sederhana dan mudah dipahami serta bisa diaplikasikan dalam kehidupan sehari-hari. Penanaman pendidikan karakter mulai dari kebiasaan melakukan doa bersama pada awal pelajaran, kebiasaan mengucap salam pada guru yang dijumpai, datang ke sekolah tepat waktu, peduli lingkungan dengan melakukan piket kelas dan halaman. 
Kompetensi keahlian di SMK 2 Negara ada 6 kompetensi yakni Kompetensi Keahlian Agribisnis Pengolahan Hasil Perikanan, Teknik dan Bisnis Sepeda Motor, Teknik Kendaraan Ringan dan Otomotif, Agribisnis Ternak Unggas, Agribisnis Tanaman Pangan dan Holtikultura, dan Nautika Kapal Penangkapan Ikan. Dari keenam kompetensi keahlian tersebut, peserta didik kelas X yang belajar di Kompeteni Agribisnis Pengolahan Hasil Perikanan, Agribisnis Ternak Unggas, Agribisnis Tanaman Pangan dan Holtikultura, dan Nautika Kapal Penangkapan Ikan yang mendapat pelajaran biologi.

Kelas X merupakan kelas awal di SMK, peserta didik di kelas ini termasuk kategori menginjak dewasa. Menurut Stanley Hall, seorang psikolog dari Amerika Serikat, merupakan salah satu perintis kajian ilmiah tentang siklus hidup (life span) yang berteori bahwa perubahan menuju dewasa terjadi dalam sekuens (urutan) yang universal bagian dari proses evolusi, parallel dengan perkembangan psikologis, namun demikian, faktor lingkungan dapat mempengaruhi cepat lambatnya perubahan tersebut (Sunardi dan Sujadi, 2017).

Siswa sebagai subyek pembelajaran merupakan individu aktif dengan berbagai karakteristiknya, sehingga dalam pembelajaran terjadi interaksi timbal balik, baik antara guru dengan siswa maupun siswa dengan siswa. Oleh karena itu, salah satu dari kompetensi pedagogik yang harus dikuasai guru adalah memahami karakteristik anak didiknya, sehingga tujuan pembelajaran, materi yang disiapkan, dan metode yang dirancang untuk menyampaikannya benar-benar sesuai dengan karakteristik siswanya. Usia anak kelas X SMK adalah kisaran 15 tahun, menurut Jean Peaget, tahap ini juga disebut masa proportional thinking. Pada masa ini, anak sudah mampu berpikir tingkat tinggi, seperti berpikir secara deduktif, induktif, menganalisis, mensintesis, mampu berpikir secara abstrak dan secara reflektif, serta mampu memecahkan berbagai masalah. (Sunardi dan Sujadi, 2017). Berpikir kreatif menurut Saddhono, Hasanudin,
Fitrianingsih (2019) selalu dibutuhkan setiap saat, terlebih dalam menjawab pertanyaan dari pendidik.

Selain penguasaan kompetensi pedagogik, guru juga harus membimbing dan membentuk karakter siswa selama belajar di kelas. Bimbingan yang diberikan oleh guru bisa disesuaikan dengan tahap perkembangan moral anak, dimana usia anak SMK menurut Erick Homburger Erickson adalah Identity vs role confusion usia 12-18 tahun. Pada tahap Identity vs role confusion (asolescence-remaja), anak dihadapkan pada kondisi pencarian identitas diri. Jati diri ini akan berpengaruh besar pada masa depannya. Pengaruh lingkungan sangat penting. Lingkungan yang baik akan menjadikan anak memiliki jati diri sebagai orang baik, sebaliknya lingkungan yang tidak baik akan membawanya menjadi pribadi yang kurang baik. Orang tua harus menjamin bahwa anak berada dalam lingkungan yang baik, sehingga hal-hal yang tidak diinginkan tidak terjadi, misalnya menjadi anggota geng anak nakal, anak jalanan, pemabuk, narkoba, dll., adalah disebabkan karena anak keliru dalam membangun identitas diri (Sunardi dan Sujadi, 2017).

Berdasarkan pengamatan selama semester awal tahun pelajaran 2018/2019, peserta didik kelas X PHP 2 cenderung kurang baik, misalnya kurangnya kesadaran piket di pagi hari, kurang menjaga kebersihan kelas, tidur selama pelajaran berlangsung, rendahnya minat belajar, kurangnya motivasi belajar, misalnya tidak gembira dan senang hati dalam belajar, sering menguap, tidak berusaha mengajukan pertanyaan dan tidak berani menjawab pertanyaan, tidak memperhatikan penjelasan guru, tidak bersungguh-sungguh dalam belajar dan tidak aktif dalam diskusi serta masih ada beberapa siswa yang nilai pengetahuan biologinya di bawah KKM, hal ini bisa dilihat dari hasil ulangan akhir semester ganjil. Sehingga selama mengajar ilmu biologi di kelas, perlu penanaman pendidikan karakter yang bisa membentuk disiplin dan karakter anak, melalui berbagai cara yang bisa dilakukan oleh guru biologi khususnya. Selain penanaman pendidikan 
karakter, juga perlu adanya model pembelajaran yang bisa meningkatkan motivasi dan hasil belajar siswa.

Menanggapi permasalahan di atas, penulis mengharapkan siswa siswi SMK Negeri 2 Negara memiliki karakter yang baik, menyukai pelajaran biologi serta mampu menemukan konsep belajar biologi dengan cara pembelajaran berpikir tingkat tinggi, maka rumusan masalah dalam penelitian ini diajukan sebagai berikut : 1) Bagaimana penerapan pembelajaran Discovery Learning dan integrasi pendidikan karakter dalam meningkatkan motivasi belajar siswa ? 2) Bagaimana penerapan pembelajaran Discovery Learning dan integrasi pendidikan karakter dalam meningkatkan hasil belajar siswa?

Adapun tujuan penelitian ini adalah siswa dapat meningkatkan motivasi dan

Tabel 1. Implementasi Pendidikan karakter dalam satuan pendidikan hasil belajar biologi melalui pembelajaran Discovery Learning dan integrasi pendidikan karakter dalam pembelajaran biologi. Sani dalam Priansa (2017). menyatakan bahwa pembelajaran penemuan adalah upaya menemukan konsep melalui pengamatan atau percobaan. Pembelajaran penemuan merupakan metode pembelajaran kognitif yang menuntut guru untuk lebih kraetif menciptakan situasi yang dapat membuat peserta didik belajar aktif menemukan pengetahuan sendiri.

Implementasi pendidikan karakter dalam satuan pendidikan diwujudkan melalui pembelajaran aktif dengan penilaian berbasis kelas disertai dengan program remediasi dan pengayaan dapat dilihat pada tabel berikut.

\begin{tabular}{ll}
\hline 1. Integrasi dalam Mata & Mengembangkan Silabus dan RPP pada kompetensi yang telah ada \\
Pelajaran & sesuai dengan nilai yang akan diterapkan \\
2. Integrasi dalam Muatan & - Ditetapkan oleh Satuan Pendidikan/ Daerah \\
& - Kompetensi dikembangkan oleh Satuan Pendidikan/daerah \\
3. Kegiatan & Pembudayaan dan Pembiasaan \\
& - Pengkondisian \\
& - Kegiatan rutin \\
& - Kegiatan Spontanitas \\
& - Keteladanan \\
& - Kegiatan terprogram \\
& Ekstrakurikuler \\
& Pramuka, PMR, UKS, Olahraga, Seni, OSIS \\
& Bimbingan Konseling \\
& - Pemberian layanan bagi peserta didik yang bermasalah \\
\hline
\end{tabular}

Pembelajaran karakter dilakukan melalui berbagai kegiatan di kelas, di satuan pendidikan formal dan nonformal, serta di luar satuan pendidikan. Penanaman karakter dalam dunia pendidikan inilah menurut Hasanudin (2015) sering disebut sebagai pendidikan karakter.

Di kelas, pendidikan karakter dilaksanakan melalui proses belajar setiap materi pelajaran atau kegiatan yang dirancang khusus. Setiap kegiatan belajar mengembangkan kemampuan dalam ranah kognitif, afektif, konatif, dan psikomotor. Oleh karena itu, tidak selalu diperlukan kegiatan belajar khusus untuk mengembangkan nilai-nilai pada pendidikan karakter. Meskipun demikian, untuk pengembangan nilai-nilai tertentu seperti kerja keras, jujur, toleransi, disiplin, mandiri, semangat kebangsaan, cinta tanah air, dan gemar membaca dapat dikembangkan melalui kegiatan belajar yang biasa dilakukan pendidik. Untuk pengembangan beberapa nilai lain seperti peduli sosial, peduli lingkungan, rasa ingin tahu, dan kreatif memerlukan upaya pengkondisian sehingga peserta didik memiliki kesempatan untuk memunculkan perilaku yang menunjukkan nilai tersebut.

Di satuan pendidikan formal dan non formal, pembelajaran karakter dilaksanakan melalui berbagai kegiatan satuan pendidikan formal dan non formal yang diikuti seluruh peserta didik, pendidik, dan 
tenaga kependidikan. Perencanaan dilakukan sejak awal tahun pelajaran, dimasukkan ke kalender pendidikan akdemik, dan dilaksanakan sehari-hari sebagai bagian dari budaya satuan pendidikan formal dan nonformal.

Di luar satuan pendidikan formal dan nonformal, pembelajaran karakter dilaksanakan melalui kegiatan ektrakurikuler dan kegiatan lain yang diikuti oleh seluruh/ sebagian peserta didik, dirancang satuan pendidikan formal dan nonformal sejak awal tahun pelajaran atau program pembelajaran, dimasukkan ke dalam kalender akademik. (Daryanto dan Darmiatun, 2013).

\section{METODE PENELITIAN}

Penelitian ini menggunakan pendekatan kualitatif, yakni untuk mendeskripsikan peristiwa-peristiwa sebagaimana terjadi secara alami, melalui pengumpulan data dan latar belakang alami.
Jenis penelitian ini adalah penelitian tindakan kelas (PTK) karena digunakan untuk memperoleh gambaran tentang motivasi dan hasil belajar siswa selama proses pembelajaran berlangsung. Penelitian Tindakan Kelas (Classroom Action Research) menurut Arikunto, Suhardjono, dan Supardi dalam Hasanudin (2007) berfungsi untuk meningkatkan kualitas hasil praktik pembelajaran di kelas.

Penelitian ini dilaksanakan dalam 2 siklus tindakan. (Tim Pelatih Proyek PGSM, 1997). Penelitian ini dilakukan di SMK Negeri 2 Negara. Tindakan penelitian mulai dilaksanakan pada tanggal 28 Januari sampai 4 Maret 2019 pada semester II tahun ajaran 2018/2019. Subyek pada penelitian ini adalah siswa kelas X PHP 2 yang mengikuti mata pelajaran Biologi pokok bahasan Klasifikasi Makhluk Hidup berdasarkan ciri, sifat, dan tempat hidupnya.

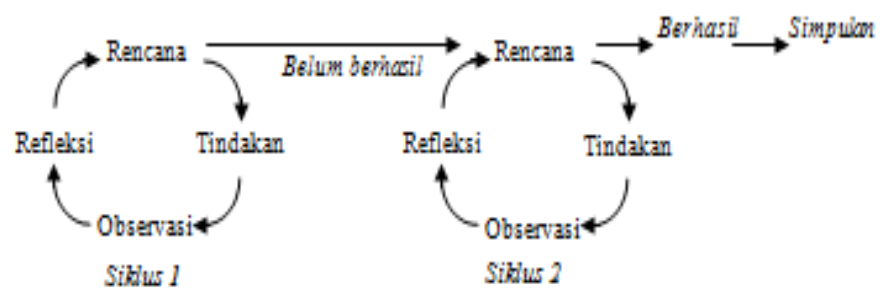

Gambar1. Tahapan Siklus Penelitian Tindakan Kelas

Rencana pelaksanaan tindakan siklus I meliputi kegiatan sebagai berikut : 1) Memilih topik bahasan, topik bahasan yang dipilih pada siklus I ini adalah klasifikasi tumbuhan dan mikroorganisme berdasarkan ciri, sifat, dan tempat hidupnya; 2) Memilih pendekatan dan strategi, pendekatan yang dipilih adalah saintifik yang meliputi $5 \mathrm{M}$ (Mengamati, Menanya, Mengumpulkan informasi, Menalar dan Mengkomunikasikan), sedangkan strategi yang digunakan adalah pembelajaran Discovery Learning; 3) Menyusun rencana pelaksanaan pembelajaran untuk klasifikasi tumbuhan dan mikroorganisme berdasarkan ciri, sifat, dan tempat hidupnya yang dialokasikan untuk 3 kali pertemuan; 4 ) Menyusun perangkat pembelajaran, meliputi; Lembar kerja Siswa, diktat, tes tertulis siklus I, kunci jawaban, rubrik soal; 5) Menyusun lembar observasi motivasi belajar, catatan lapangan, dan kegiatan guru mengajar; 6) Membentuk daftar kelompok belajar.

Pelaksanaan tindakan pada siklus I ini terdiri dari tiga kali pertemuan dengan rincian dua kali pertemuan kegiatan belajar mengajar dan satu kali ulangan harian (tes formatif 1). Kegiatan belajar mengajar dalam satu minggu dilakukan sebanyak satu kali pertemuan 2 x 45 menit. Tahap-tahap pelaksanaan tindakan yang dilakukan pada siklus I adalah sebagai berikut: 1) Guru menuliskan materi pokok pembelajaran, tujuan pembelajaran, teknik penilaian, tata tertib dalam mengikuti pembelajaran; 2) 
Guru memberikan apersepsi kemudian meminta siswa untuk mengamati, bertanya, mengumpulkan informasi; 3) Siswa berkelompok secara heterogen untuk menjawab pertanyaan yang ada di LKS; 4) Siswa mempresentasikan hasil diskusi; 5) Tes Tertulis.

Observasi dilakukan selama proses pembelajaran berlangsung. Observasi menurut Hasanudin, Fitrianingsih, dan Saddhono (2019) dilakukan untuk mengetahui kondisi sebenarnya subjek penelitian. Observasi menghasilkan lebih luas pandangan tentang masalah yang dipelajari.

Pada tahap ini dilakukan observasi terhadap motivasi, keaktifan belajar siswa dan kejadian-kejadian lain (yang tidak tercatat dalam lembar observasi) selama pembelajaran berlangsung. Sedangkan evaluasi dilaksanakan pada pertemuan terakhir dari siklus I. Berdasarkan data yang telah diperoleh dari tindakan I, maka data tersebut diolah atau dianalisis lalu dicatat kebaikan dan kelemahan dari tindakan I. Kebaikan akan diperbaiki sebagai dasar dalam pelaksanaan tindakan pada siklus II.

Rencana tindakan pada siklus II berdasarkan hasil analisis dan refleksi setelah tindakan siklus I berakhir. Tentunya pada siklus II ini akan dilakukan tindakan yang berbeda dengan siklus I guna penyempurnaan tindakan siklus I. Hal-hal yang direncanakan pada siklus II adalah sebagai berikut: 1) Memilih topik bahasan, topik bahasan yang dipilih pada siklus II ini adalah klasifikasi hewan berdasarkan ciri, sifat dan tempat hidupnya; 2) Menyusun rencana pelaksanaan pembelajaran untuk ciri-ciri makhluk hidup klasifikasi hewan berdasarkan ciri, sifat dan tempat hidupnya yang dialokasikan untuk 3 kali pertemuan; 3) Menyusun perangkat pembelajaran, meliputi; Lembar kerja siswa, diktat, tes tertulis siklus II, kunci jawaban, rubrik soal; 4)Menyusun lembar observasi, meliputi lembar observasi motivasi belajar, catatan lapangan, dan kegiatan guru mengajar.

Tindakan pada siklus II ini dilaksanakan sebanyak tiga kali pertemuan dengan rincian dua kali pertemuan kegiatan belajar mengajar dan satu kali pelaksanaan tes tertulis siklus II. Pada dasarnya, pelaksanaan tindakan pada siklus II ini sama dengan pelaksanaan tindakan pada siklus I, yakni dengan implementasi pembelajaran Discovery Learning yang dalam pelaksanaannya dilakukan perbaikan-perbaikan terhadap masalahmasalah yang muncul pada saat pelaksanaan tindakan pada siklus I.

Kegiatan observasi dilakukan sama seperti kegiatan observasi pada siklus I, yakni mengobservasi motivasi, aktivitas belajar siswa dan kejadian-kejadian lain (yang tidak tercatat dalam lembar observasi), sedangkan evaluasi dilaksanakan pada pertemuan terakhir dari siklus II, yaitu berupa tes. Refleksi pada siklus II ini dilakukan terhadap hasil observasi dan evaluasi pada siklus II sebagaimana pada siklus I. Hasil refleksi pada siklus II ini merupakan refleksi akhir dari penelitian.

Data dan Instrumen pengumpul data pada penelitian ini adalah : 1) Kehadiran peneliti, dalam penelitian ini peneliti bertindak sebagai guru dan pengumpul data, karena pendekatan yang dipilih dalam penelitian ini adalah pendekatan kualitatif dengan PTK, maka pelaksanaan penelitian ini menuntut kehadiran peneliti di lapangan; 2) Dokumentasi, dokumentasi yang digunakan dalam penelitian ini adalah berupa foto aktivitas belajar siswa dalam pembelajaran Discovery Learning; 3) Soal tes untuk setiap siklus, soal tes pada siklus I sebanyak tujuh soal uraian maupun siklus II sebanyak empat soal uraian. Untuk mengetahui peningkatan hasil belajar biologi siswa selama pembelajaran model Discovery Learning adalah dengan cara menghitung skor hasil tes pada setiap siklus. Setelah itu dicari ketuntasan belajar klasikal siswa. Dengan cara menghitung jumlah siswa yang memperoleh nilai $\geq 70$ lalu dibagi dengan jumlah siswa dalam satu kelas dan dikalikan 100\%. Seorang siswa disebut tuntas belajar apabila ia telah mencapai skor $\geq 70$ dan suatu kelas disebut tuntas belajar bila $85 \%$ di kelas tersebut telah mencapai skor $\geq 70$; (Depdikbud dalam Trianto, 2010). 4) Lembar observasi motivasi belajar siswa, lembar observasi digunakan untuk mengukur motivasi belajar siswa dengan cara klasikal mengisi format 
daftar cocok/check-list motivasi selama kegiatan pembelajaran berlangsung. Pengamatan terhadap motivasi belajar siswa terdiri dari tiga aspek yaitu: aspek minat, perhatian, dan ketekunan. Data motivasi peserta didik kemudian dikategorikan menjadi sangat baik (85\% $100 \%)$, baik $(70 \%-84 \%)$, cukup (55\% ; $69 \%)$, kurang $(50 \%-54 \%)$, sangat kurang (0-49\%); (Husen dalam Mujiati, 2005)

5) Catatan lapangan, catatan lapangan ini digunakan untuk memperoleh data secara obyektif yang tidak terekam dalam lembar observasi mengenai hal-hal yang terjadi selama pemberian tindakan; 6) Angket, angket yang diberikan kepada siswa berisi pertanyaan-pertanyaan tentang pembelajaran Discovery Learning.

\section{HASIL DAN PEMBAHASAN}

Pelaksanaan Penelitian Tindakan Kelas ini pada siklus I maupun siklus II dengan kompetensi dasar pengetahuan yakni "Menganalisis ciri, sifat dan habitat makhluk hidup sebagai komponen dalam keanekaragaman hayati", dan kompetensi dasar ketrampilan yakni "Mengklasifikasi makhluk hidup berdasarkan ciri, sifat dan lingkungan hidup sebagai komponen dalam keanekaragaman hayati dalam bidang kemaritiman", dengan materi pokok klasifikasi makhluk hidup, yakni hewan, tumbuhan dan mikroorganisme.

Pendekatan pembelajaran yang digunakan selama penelitian adalah pendekatan saintifik yang meliputi $5 \mathrm{M}$ (Mengamati, Menanya, Mengumpulkan informasi, Menalar, dan Mengkomunikasikan) dengan model pembelajaran Discovery Learning ( Stimulation/pemberian rangsang, problem statemen/pertanyaan/identifikasi masalah, data collection/pengumpulan data, data processing/pengolahan data, dan generalization/menarik kesimpulan) yang dipakai sebagai skenario pembelajaran tiap pertemuan.

Dalam pembelajaran model ini, guru menyediakan bahan pengamatan berbagai macam tumbuhan monokotil, dikotil, tanaman paku, lumut, ganggang, berbagai gambar hewan vertebrata, avertebrata, pengamatan langsung serangga yang terdapat di sekitar sekolah. Dengan adanya bahan pengamatan ini maka peserta didik belajar dengan pendekatan konstektual. Menurut Daryanto dan Darmiatun (2013) bahwa kegiatan pembelajaran dalam kerangka pengembangan karakter peserta didik dapat menggunakan pendekatan belajar konstekstual.

Pemberian stimulus pada siswa berupa bahan amatan diharapkan mampu menimbulkan pertanyaan untuk memunculkan sifat kritis dalam diri siswa tersebut. Hal ini sesuai dengan pernyataan Priansa (2017) bahwa Guru memberikan kesempatan kepada peserta didik untuk mengidentifikasi sebanyak mungkin agenda-agenda masalah yang relevan dengan bahan pelajaran. Selanjutnya agar lebih optimal pembelajaran Discovery Learning, maka guru mengelompokkan siswa menjadi 5 siswa dalam satu kelompok. Adapun jumlah siswa di kelas X PHP 2 adalah 35, maka ada 7 kelompok diskusi. Kemampuan siswa dalam kelompok adalah heterogen, sehingga siswa yang memiliki kemampuan berpikir tinggi akan membantu temannya yang berkemampuan sedang atau rendah, adapun pemilihan anggota kelompok berdasarkan nilai yang didapat di semester ganjil.

Tahapan selanjutnya adalah menyatakan masalah (problem statement), dalam hal ini guru memberikan kesempatan pada peserta didik untuk menanyakan masalah yang muncul setelah adanya stimulus yang diberikan guru. Langkah berikutnya adalah pengumpulan data. Pada tahap ini, siswa siswi berusaha menjawab pertanyaan-pertanyaan yang sebelumnya diajukan. Adapun kegiatan yang dilakukan oleh siswa siswi kelas X PHP 2 adalah membaca buku biologi, googling di internet, mengerjakan LKS tentang klasifikasi makhluk hidup, melakukan pengamatan bahan amatan yang tersedia, pengamatan langsung lingkungan sekitar. Hal ini sesuai dengan pernyataan Kosasih (2018) bahwa serangkaian pengumpulan data yakni dengan: a) membaca berbagai dokumen, b) melakukan pengamatan lapangan, c) penelitian laboratorium, d) melakukan wawancara, dan e) menyebarkan angket. Dengan cara-cara 
tersebut, diharapkan siswa dapat memperoleh data yang benar-benar faktual, kuat, dan meyakinkan. Data itu pun dapat dipertanggungjawabkan kebenarannya karena mereka sendiri yang mengumpulkan. Diharapkan data itu pun dapat memberikan jawaban atas permasalahan sebelumnya dan dibandingkan pula dengan hipotesis yang telah mereka rumuskan. Data-data itu mereka catat dalam instrumen yang telah mereka siapkan sebelumnya, baik itu yang berupa jurnal, lembar observasi/pengamatan laboratorium, dan sejenisnya. (Kosasih, 2018).

Siswa siswi yang telah selesai mengumpulkan data dan menjawab LKS yang telah diberikan, maka selanjutnya mereka akan memproses data tersebut. Masing-masing kelompok berdiskusi untuk mendapatkan kesimpulan sementara yang didapat dari jawaban LKS dan hasil pengumpulan data. Hal ini sesuai dengan yang ditulis oleh Priansa (2017) bahwa Pemrosesan data disebut juga dengan proses kodifikasi / kategorisasi yang berfungsi sebagai pembentukan konsep dan generalisasi. Dari generalisasi tersebut, peserta didik akan mendapatkan pengetahuan baru tentang alternatif jawaban / penyelesaian yang perlu mendapat pembuktian secara logis.

Langkah selanjutnya adalah verifikasi, dalam hal ini masing-masing kelompok maju ke depan untuk membacakan hasil kesimpulan sementara yang didapat dalam diskusi kelompok, sedangkan kelompok lainnya menanggapi. Guru sebagai tutor, memberikan umpan balik terhadap siswa dalam berdiskusi. Dalam hal ini, diharapkan masing-masing siswa mendapat suatu konsep, teori atau pemahaman tentang klasifikasi makhluk hidup.

Setelah didapatkan kesimpulan sementara dari masing-masing kelompok, tahap selanjutnya adalah generalisasi/menarik kesimpulan. Pada tahap ini, guru bersama siswa menarik kesimpulan yang tepat dari materi pembelajaran tentang klasifikasi makhluk hidup sehingga didapatkan suatu konsep dan teori tentang klasifikasi makhluk hidup.
Menurut Priansa (2017) bahwa Tahap generalisasi atau menarik kesimpulan merupakan proses menarik sebuah kesimpulan yang dapat dijadikan prinsip umum dan berlaku untuk semua kejadian atau masalah yang sama, dengan memerhatikan hasil verifikasi. Tahap ini juga identik dengan dirumuskannya katakata prinsip-prinsip yang mendasari generalisasi.

Pembelajaran Discovery Learning merupakan salah satu model pembelajaran yang melibatkan berpikir tingkat tinggi. Keterampilan berpikir tingkat tinggi sebagai transfer of knowledge erat kaitannya dengan keterampilan berpikir sesuai ranah kognitif, afektif, dan psikomotor. Ranah kognitif meliputi kemampuan dari peserta didik dalam mengulang atau menyatakan kembali konsep/prinsip yang telah dipelajari dalam proses pembelajaran yang telah didapatnya. Proses ini berkenaan dengan kemampuan dalam berpikir, kompetensi dalam mengembangkan pengetahuan, pengenalan, pemahaman, konseptualisasi, penentuan dan penalaran. (Ariyana, dkk., 2018).

Siswa siswi di kelas X PHP 2 memiliki karakter yang berbeda-beda, dari jumlah siswa 35 anak, yang perempuan hanya tiga anak dan sisanya laki-laki. Dalam kegiatan sehari-hari, yang laki-laki cenderung bersikap kurang bersih terutama pada saat piket kelas, karena gaya hidup mereka di rumah yang mengandalkan tenaga orangtuanya untuk membersihkan rumah. Dari pengalaman ini, maka untuk piket sehari-hari, wali kelas berusaha mengingatkan mereka agar piket sesuai jadwal dan tidak menggantungkan pada teman perempuannya yang jumlahnya hanya tiga anak.

Dalam pembelajaran biologi, guru mengintegrasikan pendidikan karakter selama mengajar. Pada awal pelajaran, guru memantau ke sekitar kelas dan dalam ruangan, jika ada yang kurang bersih atau ada sampah berserakan di dalam ruangan, maka guru akan memanggil petugas piket di hari tersebut untuk membersihkan sampah dan lantai yang kurang bersih. Selanjutnya guru mengucap salam pembuka pada siswa siswi. Jika ada yang kurang 
keras dalam membalas salam, maka guru akan mengulanginya lagi supaya mereka menjawab salam dengan keras, sehingga pada awal pelajaran akan muncul semangat untuk mengikuti pelajaran. Bagi siswa yang mengantuk, maka guru akan menyuruhnya mencuci muka.

Gerakan literasi juga dimunculkan dalam kegiatan belajar mengajar biologi di kelas. Pada awal pembelajaran, siswa siswi diharuskan membaca apapun terlebih bagus jika membaca pelajaran biologi selama lima menit awal. Setelah literasi, siswa siswi tersebut mengucap doa untuk memulai belajar biologi. Adapun model pembelajaran yang diterapkan adalah Discovery Learning. Intregasi pendidikan karakter dalam pembelajaran biologi dengan model pembelajaran ini sangat membantu siswa dalam meningkatkan motivasi dan hasil belajar mereka, karena dengan dua cara ini mereka akan tergerak untuk memperbaiki kualitas diri yang dibuktikan dengan adanya perubahan karakter menjadi lebih baik dan kemampuan akademik mereka meningkat dengan pembelajaran tingkat tinggi seperti Discovery learning.

Pengintegrasian pendidikan karakter dalam pembelajaran biologi dipadukan dengan model pembelajaran Discovery Learning sangat bagus untuk meningkatkan motivasi belajar dan hasil belajar mereka. Misalnya membersihkan sampah yang berserakan dan menyapu ruang kelas dan halaman merupakan karakter peduli lingkungan, mengucap salam dan doa pada awal pembelajaran sebagai karakter religius, gerakan literasi pada awal pembelajaran sebagai karakter gemar membaca, memberikan respon terhadap stimulus yang diberikan guru kemudian keaktifan bertanya adalah karakter rasa ingin tahu, mengerjakan LKS dengan kelompoknya adalah karakter jujur, kerja keras, mau mempresentasikan hasil diskusi dan memberi tanggapan pada kelompok lain adalah karakter semangat kebangsaan, bersahabat/komunikatif. Hasil pembelajaran ini merupakan cerminan dari sebagian nilai karakter hasil kajian empirik Pusat Kurikulum. Hal ini sesuai dengan yang ditulis Daryanto dan Darmiatun (2013) bahwa dalam rangka lebih memperkuat pelaksanaan pendidikan karakter telah teridentifikasi 18 nilai yang bersumber dari agama, pancasila, budaya, dan tujuan pendidikan nasional, yaitu: (1) Religius, (2) Jujur, (3) Toleransi, (4) Disiplin, (5) Kerja keras, (6) Kreatif , (7) Mandiri, (8) Demokratis, (9) Rasa Ingin Tahu, (10) Semangat Kebangsaan, (11) Cinta Tanah Air, (12) Menghargai Prestasi, (13) Bersahabat/Komunikatif, (14) Cinta Damai, (15) Gemar Membaca, (16) Peduli Lingkungan, (17) Peduli Sosial, dan (18) Tanggung Jawab. (Daryanto dan Darmiatun, 2013).

Dari hasil penelitian didapatkan bahwa ketuntasan belajar siswa mengalami kenaikan setelah diterapkannya pembelajaran model Discovery Learning.

Prosentase keberhasilan/ketuntasan belajar siswa pada siklus I

$\checkmark$ Yang tidak tuntas $=8 / 35 \times 100 \%=$ $22,86 \%$

$\checkmark \quad$ Yang tuntas $=27 / 35 \times 100 \%=77,14 \%$

$\checkmark \quad$ Nilai rata-rata siswa $=71,11$

Prosentase keberhasilan/ketuntasan belajar siswa pada siklus II

$$
\begin{aligned}
& \checkmark \quad \text { Yang tidak tuntas }=4 / 35 \times 100 \\
& \%=11,43 \% \\
& \checkmark \quad \text { Yang tuntas }=31 / 35 \times 100 \%=88,57 \% \\
& \checkmark \quad \text { Nilai rata-rata }=73,89 \\
& \text { Dari data diatas dapat dibuat tabel } \\
& \text { sebagai berikut. }
\end{aligned}
$$

Tabel 2. Ketuntasan belajar siswa siklus I dan siklus II

\begin{tabular}{llccc}
\hline No & Tindakan & Belum tuntas $(\%)$ & Tuntas $(\%)$ & Nilai rata-rata \\
\hline 1 & Siklus I & 22,86 & 77,14 & 71,11 \\
2 & Siklus II & 11,43 & 88,57 & 73,89 \\
\hline
\end{tabular}


Pencapaian prestasi belajar siswa kelas X PHP 2 pada siklus I dan siklus II berdasarkan hasil penelitian mengalami kenaikan sebesar $11,43 \%$. Pada siklus I jumlah siswa yang tidak tuntas ada 8 orang, dengan prosentase $22,86 \%$, kemudian pada siklus II mengalami penurunan jumlah siswa yang tidak tuntas ada 4 orang, dengan prosentase $11,43 \%$, hal ini menandakan bahwa jumlah siswa yang tuntas mengalami kenaikan. Hal ini sesuai dengan angket yang menyatakan bahwa "Dengan berusaha menjawab pertanyaan di LKS, saya jadi lebih terbiasa untuk menjawab soal-soal ujian tanpa ada beban", ada 8 siswa yang menjawab sangat setuju, 26 siswa menjawab setuju dan 1 siswa masih raguragu. Kemudian angket berikutnya yang menyatakan "Saya yakin dengan pembelajaran kooperatif model Discovery Learning, nilai saya dapat meningkat", ada 15 siswa menjawab sangat setuju dan 20 siswa menjawab setuju.

Untuk data motivasi belajar juga mengalami kenaikan dari tindakan siklus I dan siklus II.

Table 3. Data Analisis Motivasi Siswa Siklus I dan Siklus II

\begin{tabular}{|c|c|c|c|c|c|}
\hline Deskriptor & Motivasi siswa & $\begin{array}{l}\text { Rerata p } \\
\text { siswa } \\
\text { mela } \\
\text { deskrip } \\
\text { Siklus } \\
\text { I }\end{array}$ & $\begin{array}{l}\text { rsentase } \\
\text { yang } \\
\text { ukan } \\
\text { or (\%) } \\
\text { Siklus } \\
\text { II }\end{array}$ & $\begin{array}{l}\text { Selisih } \\
(\%)\end{array}$ & Keterangan \\
\hline 1 & $\begin{array}{l}\text { Siswa mengikuti kegiatan belajar } \\
\text { pembelajaran dengan gembira dan senang } \\
\text { hati }\end{array}$ & 90,00 & 95,72 & 5,72 & Meningkat \\
\hline 2 & $\begin{array}{l}\text { Tidak mengantuk ketika mengikuti } \\
\text { pembelajaran yang ditandai dengan tidak } \\
\text { sering menguap }\end{array}$ & 84,29 & 90,00 & 5,71 & Meningkat \\
\hline 3 & $\begin{array}{l}\text { Siswa berusaha mengajukan pertanyaan } \\
\text { jika ada yang tidak diketahui }\end{array}$ & 60,00 & 61,43 & 1,43 & Meningkat \\
\hline 4 & $\begin{array}{l}\text { Siswa berani menjawab pertanyaan yang } \\
\text { diajukan teman maupun guru }\end{array}$ & 58,58 & 58,57 & 0,01 & Meningkat \\
\hline 5 & Siswa memperhatikan penjelasan guru & 84,29 & 92,86 & 8,57 & Meningkat \\
\hline 6 & $\begin{array}{l}\text { Siswa tidak bercakap-cakap sendiri selain } \\
\text { yang berhubungan dengan pelajaran } \\
\text { ketika guru menjelaskan }\end{array}$ & 74,29 & 91,43 & 17,14 & Meningkat \\
\hline 7 & $\begin{array}{l}\text { Siswa mengikuti semua instruksi yang } \\
\text { diajukan oleh guru }\end{array}$ & 84,29 & 94,29 & 10 & Meningkat \\
\hline 8 & $\begin{array}{l}\text { Siswa bersungguh-sungguh untuk } \\
\text { menjawab pertanyaan yang terdapat di } \\
\text { LKS }\end{array}$ & 84,29 & 85,72 & 1,43 & Meningkat \\
\hline 9 & $\begin{array}{l}\text { Siswa aktif dalam diskusi kelompok dan } \\
\text { diskusi kelas }\end{array}$ & 58,57 & 64,29 & 5,72 & Meningkat \\
\hline & Jumlah Prosentase & 678,60 & 734,31 & 55,71 & Meningkat \\
\hline & Rata-rata prosentase & 75,4 & 81,59 & 6,19 & Meningkat \\
\hline
\end{tabular}

Dari data motivasi belajar diatas ratarata prosentase dari siklus I ke siklus II mengalami kenaikan sebesar 6,19\%. Kenaikan yang signifikan terjadi pada deskripsi motivasi " Siswa tidak bercakapcakap sendiri selain yang berhubungan dengan pelajaran ketika guru menjelaskan" sebesar 17,14\% dan "Siswa memperhatikan penjelasan guru" sebesar $8,57 \%$. Siswa juga mengikuti semua instruksi yang diberikan guru mengalami kenaikan prosentase sebesar $10 \%$. Dalam pembelajaran model Discovery Learning ini guru bertindak sebagai motivator, pembimbing atau tutor. Guru hendaknya tidak mengungkapkan terlebih dahulu prinsip atau aturan yang akan dipelajari, tetapi memberikan saransaran jika diperlukan. Sebagai tutor, guru 
memberikan umpan balik pada waktu yang tepat.

Deskripsi motivasi berikutnya yang mengalami kenaikan sebesar 5,72\% dan $5,71 \%$ adalah "Siswa mengikuti kegiatan belajar pembelajaran dengan gembira dan senang hati" dan "Tidak mengantuk ketika mengikuti pembelajaran yang ditandai dengan tidak sering menguap". Hal ini sesuai dengan angket siswa yang menyatakan bahwa "Saya senang belajar biologi dengan model Discovery Learning" ada 13 siswa menjawab sangat setuju, 20 siswa menjawab setuju, tetapi ada juga 2 siswa menjawab ragu-ragu. Angket berikutnya yang mendukung adalah "Dengan pembelajaran model Discovery Learning, saya lebih bersemangat mempelajari biologi" ada 31 siswa menjawab setuju. Motivasi yang dialami peserta didik diatas adalah motivasi instrinsik (rangsangan dari dalam diri peserta didik), dengan adanya motivasi tersebut siswa lebih senang dan semangat mengikuti pembelajaran. Hal ini sesuai yang ditulis oleh Priansa (2017) bahwa faktor individual yang mendorong seseorang untuk melakukan sesuatu adalah minat, peserta didik merasa terdorong untuk belajar jika kegiatan belajar tersebut sesuai minatnya.

Deskripsi motivasi " Siswa aktif dalam diskusi kelompok dan diskusi kelas" mengalami kenaikan sebesar 5,72\% dan "Siswa bersungguh-sungguh untuk menjawab pertanyaan yang terdapat di LKS" mengalami kenaikan sebesar 1,43\% dengan prosentase pada siklus I sebesar $84,29 \%$ dan siklus II sebesar 85,72\%. Dari data tersebut menandakan bahwa siswa antusias dalam diskusi baik diskusi kelompok ketika mengerjakan LKS maupun diskusi kelas membahas hasil dari masing-masing kelompok. Hal ini sesuai yang ditulis oleh Priansa (2017) bahwa peserta didik yang mempunyai sifat positif terhadap suatu kegiatan akan berusaha sebisa mungkin menyelesaikan kegiatan tersebut dengan sebaik-baiknya. Motivasi pada dasarnya sudah ada di dalam diri setiap peserta didik. Peserta didik mempunyai kebutuhan tertentu dan akan berusaha melakukan kegiatan apapun sesuai dengan kebutuhannya.

Deskripsi motivasi yang mengalami kenaikan sedikit yakni $0,01 \%$ adalah "Siswa berani menjawab pertanyaan yang diajukan teman maupun guru" dan 1,43\% adalah Siswa berusaha mengajukan pertanyaan jika ada yang tidak diketahui. Dari penelitian ini didapat bahwa walaupun peningkatan prosentasenya sedikit tetapi masih ada usaha dari siswa untuk berani bertanya dan menjawab pertanyaan. Hal ini didukung oleh angket yang diisi siswa yang menyatakan "Hal yang paling menyenangkan pada saat pembelajaran model Discovery Learning adalah pada saat diskusi dan presentasi, siswa yang menjawab setuju ada 27 anak, dan 8 siswa menjawab ragu-ragu.

Berdasarkan data-data diatas bahwa pembelajaran model Discovery Learning dapat meningkatkan motivasi dan hasil belajar siswa. Kenaikan prosentase hasil belajar dari siklus I ke siklus II sebesar $11,43 \%$ dan kenaikan motivasi belajar dari siklus I ke siklus II sebesar 6,19\%. Dengan model pembelajaran ini guru berusaha menjadi salah satu faktor yang mempengaruhi motivasi siswa. Upaya yang dimaksud guru adalah cara guru mempersiapkan strategi dalam memotivasi peserta didik agar mampu mengoptimalkan seluruh potensi yang ada dalam diri peserta didik (Priansa, 2017).

\section{SIMPULAN}

Berdasarkan hasil tindakan yang telah dilaksanakan pada siklus I dan siklus II dapat disimpulkan hal-hal berikut : 1) Penerapan pembelajaran model Discovery Learning yang terintegrasi pendidikan karakter dapat meningkatkan motivasi belajar siswa, motivasi belajar siswa meningkat dari siklus I sebesar 75,40\% menjadi $81,59 \%$ pada siklus II, peningkatan sebesar $6,19 \%$; 2) Penerapan pembelajaran model Discovery Learning yang terintegrasi pendidikan karakter dapat meningkatkan ketuntasan belajar siswa. Pada siklus I, jumlah siswa yang tuntas belajar sebesar $77,14 \%$ meningkat menjadi $88,57 \%$ pada siklus II. 


\section{DAFTAR RUJUKAN}

Ariyana, Y. dkk. (2018). Pembelajaran berorintasi pada keterampilan berpikir tingkat tinggi program peningkatan kompetensi pembelajarn berbasis zonasi. Jakarta, Indonesia: Direktorat Jenderal Guru dan Tenaga Kependidikan Kementerian Pendidikan dan Kebudayaan.

Daryanto dan Darmiatun, S. (2013). Implementasi pendidikan karakter di sekolah. Yogyakarta, Indonesia: Gava Media.

Hasanudin, C. (2015). Representasi nilai feminis tokoh amba dalam novel amba karya laksmi pamuntjak (sebuah analisis wacana sara mills dan nilai pendidikan karakter). BUANA BASTRA: Bahasa, Susastra, dan Pengajarannya, 2(2), 132-147. Retrieved from http://jurnal.unipasby.ac.id/index.ph p/bastra/article/view/230.

Hasanudin, C. (2017). The implementation of mind mapping method as an effort to improve narrative writing skill of the fourth-grade students of Islamic Primary School. Proceeding International Seminar of Primary Education, 1, 40-46. Retrieved from http://prosiding.unipma.ac.id/index. php/ISPE/article/view/126.

Hasanudin, C., Fitrianingsih, A., Saddhono, K. (2019). How is the student's negotiation text in collaborative learning of flipped classroom and a CyberLink power director media apps. Ingénierie des Systèmes d'Information, Vol. 24, No. 6, pp. 559-567.

https://doi.org/10.18280/isi.240601.

Kosasih. (2018). Startegi belajar dan pembelajaran. Bandung, Indonesia: Yrama Media.

Mujiati, W. (2005). Penerapan metode pembelajaran kooperatif model jigsaw untuk meningkatkan motivasi dan prestasi belajar biologi siswa kelas $2 D$ semester II SMP 1 Malang. Skripsi Tidak Diterbitkan. Malang: Jurusan Biologi FMIPA UM.

Priansa, D. J. (2017). Pengembangan strategi \& model pembelajaran. Bandung, Indonesia: CV. Pustaka Setia.

Saddhono, K., Hasanudin, C., Fitrianingsih, A. (2019). The ability to think creatively on SSCS using schoology Apps, how is the student's language metacognitive awareness? Ingénierie des Systèmes d'Information, 24(4), 367-375.

Doi https://doi.org/10.18280/isi.240402 .

Sunardi dan Sujadi, I. (2017). Sumber belajar kompetensi pedagogik untuk calon peserta program PLPG. Jakarta, Indonesia: Direktorat Jenderal Guru dan Tenaga Kependidikan Kementerian Pendidikan dan Kebudayaan

Tim Pelatih Proyek PGSM. (1999). Penelitian tindakan kelas (Classroom Action Research). Jakarta, Indonesia: Departemen Pendidikan dan Kebudayaan Direktorat Jenderal Pendidikan Tinggi Proyek Pengembangan Guru Sekolah Menengah.

Trianto. (2010). Mendesain model pembelajaran inovatif-progresif: Konsep, landasan, dan implementasinya pada Kurikulum Tingkat Satuan Pendidikan (KTSP). Jakarta, Indonesia: Kencana Prenada Media Group. 
20 JURNAL PENDIDIKAN EDUTAMA, Vol.7, No.1 Januari 2020 